\title{
Testosterone and Estradiol are Co-secreted Episodically by the Human Testis
}

Stephen J. Winters and Philip Troen

Department of Medicine, Montefiore Hospital and University of Pittsburgh School of Medicine, Pittsburgh, Pennsylvania 15213

\begin{abstract}
In spite of a striking pulsatile pattern of luteinizing hormone (LH) secretion, testosterone (T) fluctuations in peripheral blood in normal adult men are irregular and of low amplitude. To determine whether $\mathbf{T}$ secretion by the human testis is episodic, $T$ was measured in blood samples drawn at 15-min intervals for 4 $h$ through a catheter placed in the testicular vein of six men with varicocele-associated infertility. Estradiol $\left(\mathbf{E}_{2}\right)$ concentrations were also determined in each sample. Each subject released testosterone in well-defined pulses. Gonadal vein $\mathbf{T}$ levels ranged from 1 to $1,540 \mathrm{ng} / \mathrm{ml}$. Mean ( \pm SE) pulse amplitude was $176 \pm 42$ $\mathrm{ng} / \mathrm{ml}$, with a frequency of $4.0 \pm 0.3$ pulses per $4 \mathrm{~h}$. Testicular vein $E_{2}$ levels ranged from 0.01 to $6.8 \mathrm{ng} / \mathrm{ml}$. $E_{2}$ secretory episodes were generally coincident with $T$ pulses, and their amplitudes were highly positively correlated $(r=0.90, P<0.01)$.

These results indicate that $T$ secretion by the adult human testis is pulsatile, and suggest a functional relationship between intermittent LH secretion and normal testicular steroidogenesis in men. The failure to appreciate these fluctuations as hormone pulses in peripheral blood may relate to their absolute amplitude and frequency. The concordance between $E_{2}$ and $T$ pulses suggests that the Leydig cell, under LH control, is the source of most of the $E_{2}$ secreted by the adult human testis.
\end{abstract}

\section{Introduction}

Luteinizing hormone (LH) ${ }^{1}$ is secreted by the pituitary gland into the peripheral blood in distinct bursts (1) which have been shown to be a consequence of intermittent luteinizing hormonereleasing hormone (LRH) release by the hypothalamus (2). The gonadotroph requires this intermittent secretory mode for it to function normally (3). Temporal co-analysis of circulating $\mathrm{LH}$ and testosterone (T) levels in many male laboratory animals, including subhuman primates, reveals a tight coupling of $\mathrm{LH}$ pulses to subsequent $T$ secretory episodes, which indicates a functional relationship between intermittent gonadotropin secretion and the steroidogenic function of the testis (4-7). This relationship has not previously been established in men.

$T$ fluctuations in peripheral blood in men are of low amplitude and occur at irregular intervals (8-12). In one study, T increments in men were generally preceded by LH rises, but

Portions of these data were published in abstract form (Clin. Res. 1985. 33:318A, and in J. Androl. 1986. 7:26-P).

Reccived for publication 4 March 1986.

1. Abbreviations used in this paper: $\mathrm{E}_{2}$, estradiol; $\mathrm{FSH}$, follicle-stimulating hormone; hCG, human chorionic gonadotropin; LH, luteinizing hormone; $\mathrm{LRH}$, luteinizing hormone-releasing hormone; $\mathrm{T}$, testosterone.

J. Clin. Invest.

(C) The American Society for Clinical Investigation, Inc.

0021-9738/86/10/0870/04 \$1.00

Volume 78, October 1986, 870-873 only one of three LH pulses was followed by a rise in serum $\mathrm{T}$ levels (12). Some investigators have been unable to identify any convincing relationship between $\mathrm{LH}$ and $\mathrm{T}$ pulses $(8,10)$, whereas a statistically significant correlation between $\mathrm{LH}$ and $\mathrm{T}$ concentrations with a phase delay of 1-3 h has also been described (11). In an occasional subject, a large peak of LH bioactivity will be followed by a convincing rise in circulating $T$ levels (13).

To determine whether $T$ secretion by the human testis is episodic under physiologic conditions, $T$ was measured in blood samples drawn at 15-min intervals for $4 \mathrm{~h}$ through a catheter placed in the gonadal vein of six men with varicocele-associated infertility who were undergoing gonadal venography. Estradiol $\left(E_{2}\right)$ levels were also examined to compare the patterns of $T$ and $\mathrm{E}_{2}$ secretion in men.

\section{Methods}

Six men, ages 30-41 yr, with varicocele-associated infertility, volunteered for this study, which was approved by the Human Investigation Committee of Montefiore Hospital. Their clinical characteristics are summarized in Table I. Mean circulating LH, follicle-stimulating hormone (FSH), and T levels were normal for each man. Varicocele was visible and/or palpable when each patient assumed the upright posture. The internal spermatic vein (five patients on the left, one on the right) was catheterized using a femoral vein approach. Premedication with meperidine was avoided, since narcotic drugs inhibit gonadotropin secretion. The subjects were returned to a quiet room for the sampling study. Blood was sampled every $15 \mathrm{~min}$ for $4 \mathrm{~h}$, allowed to clot at room temperature, and the serum was stored at $-20^{\circ} \mathrm{C}$ for subsequent radioimmunoassay. All samples from an individual subject were analyzed in a single assay to eliminate the influence of interassay variation.

Serum concentrations of $T$ and $E_{2}$ were determined in samples diluted 1:10 to 1:400 with phosphate-buffered saline, which were then ether extracted. The $E_{2}$ fraction was purified by chromatography on Sephadex LH-20 using chloroform- $n$-hepatane-methanol-water (200:200:30:1.2, $\mathrm{vol} / \mathrm{vol} / \mathrm{vol} / \mathrm{vol}$ ) as the solvent system. This step completely separated radiolabeled $T$ from $E_{2}$. Separation of antibody-bound from free steroid was accomplished with dextran-charcoal. The assay sensitivities were $<25 \mathrm{pg} /$ tube for testosterone and $4 \mathrm{pg} /$ tube for $\mathrm{E}_{2}$. Anti- $\mathrm{E}_{2}$ antiserum raised in our laboratory cross-reacted $0.03 \%$ with testosterone. The within assay coefficient of variation was $4.9 \%$ for testosterone and $6.3 \%$ for $E_{2}$. The level of T-binding globulin was measured by the method of Nisula et al. (14). Steroids were first removed from the samples by treatment overnight with dextran-charcoal at $2^{\circ} \mathrm{C}$, and this was followed by retreatment for $1 \mathrm{~h}$ at $37^{\circ} \mathrm{C}$. Serum $\mathrm{LH}$ and FSH concentrations were measured using double antibody radioimmunoassays (RIAs) using LER907 as the reference standard.

A hormone pulse was defined as an increase above the preceding nadir value of at least twice the within-assay coefficient of variation (15). Correlation coefficient was calculated by a least-squares linear regression.

\section{Results}

The mean $( \pm \mathrm{SE})$ gonadal vein $\mathrm{T}$ level was $306 \pm 142 \mathrm{ng} / \mathrm{ml}, \sim 50$ times the $T$ concentration in peripheral blood. Individual values varied from 1 to $1,540 \mathrm{ng} / \mathrm{ml}$. Serial measurements in gonadal 
Table I. Sperm Counts and Circulating Hormone Concentrations

\begin{tabular}{llllll}
\hline Subject & $\begin{array}{l}\text { Sperm } \\
\text { density }\end{array}$ & FSH & LH & T & $E_{2}$ \\
\hline & million/ml & $n g / m l$ & $n g / m l$ & $n g / d l$ & $p g / m l$ \\
1 & 2.9 & 238 & 34 & 626 & 16 \\
2 & 25.9 & 135 & 38 & 347 & 15 \\
3 & 1.7 & 122 & 17 & 461 & 12 \\
4 & 7.1 & 265 & 66 & 392 & 17 \\
5 & 1.5 & 147 & 113 & 925 & 25 \\
6 & 4.2 & 109 & 77 & 570 & 26 \\
Mean \pm SE & $7.2 \pm 3.8$ & $169 \pm 27$ & $58 \pm 14$ & $554 \pm 86$ & $18 \pm 2$ \\
Normal men & $>20$ & $<290$ & $<150$ & $300-1,100$ & $<50$ \\
& & & & & \\
\hline
\end{tabular}

vein serum revealed that $T$ secretion in each subject was clearly pulsatile (Fig. 1). Sampling at 15-min intervals revealed hourly $T$ pulses (4.0 0.3 , range 3-5, pulses per $4 \mathrm{~h}$ ). Mean pulse amplitude was $176 \pm 42 \mathrm{ng} / \mathrm{ml}$, which represented an increase of $6.6 \pm 2.3$-fold from the prepulse nadir to the peak. For each of the subjects, $\mathrm{T}$ pulse amplitude was highly variable.

Testicular vein $\mathrm{E}_{2}$ concentrations were $1.35 \pm 0.83 \mathrm{ng} / \mathrm{ml}$, $\sim 75$ times the levels in peripheral blood. Individual values were highly variable, ranging from 0.01 to $6.8 \mathrm{ng} / \mathrm{ml}$. $E_{2}$ secretion in each of the six subjects was also strikingly pulsatile (Fig. 1). Mean pulse amplitude was $0.74 \pm 0.28 \mathrm{ng} / \mathrm{ml}$, an increase of $4.7 \pm 1.2$ fold from basal to peak. As for testosterone, $E_{2}$ pulse frequency was approximately one pulse per hour ( $3.5 \pm 0.4$ pulses per $4 \mathrm{~h}$ ).

Examination of $T$ and $E_{2}$ secretory pulses revealed a striking concordance in both timing and amplitude (Fig. 1). Fig. 2 compares the absolute amplitudes of coincident $\mathrm{T}$ and $\mathrm{E}_{2}$ pulses; they were highly positively correlated $(r=0.90, P<0.01)$. Fig. 3 compares serial measurements of testosterone in gonadal and peripheral blood in a representative subject. The pulsatile mode of $\mathrm{T}$ secretion is not evident from the moment-to-moment changes in peripheral blood testosterone. Further, peaks of testosterone in peripheral blood are not uniformly associated with testosterone secretory pulses observed in gonadal vein blood.

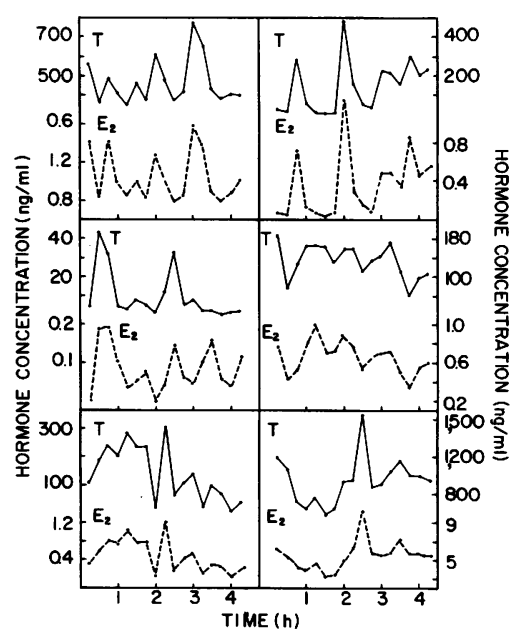

Figure 1. Gonadal vein serum concentrations of testosterone and $E_{2}$ in six men with varicocele-associated infertility. Blood was sampled at 15-min intervals for $4 \mathrm{~h}$.

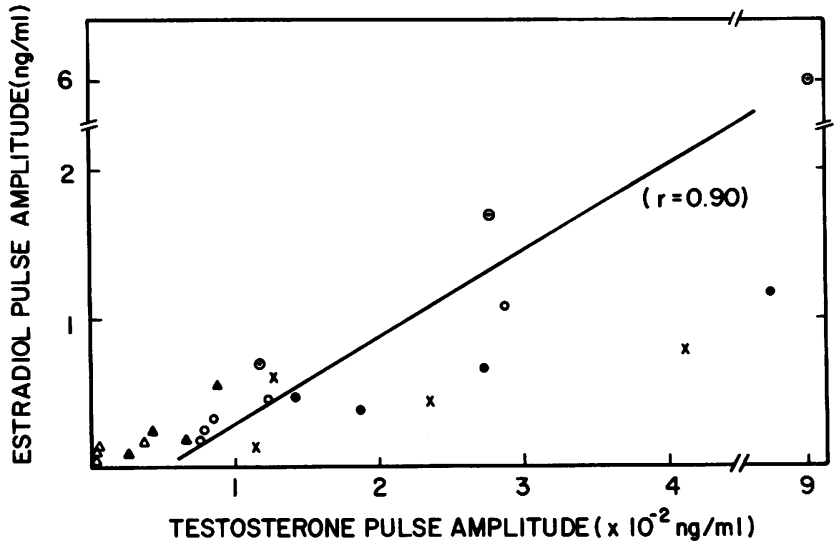

Figure 2. The correlation between the amplitude of each $\mathrm{T}$ secretory pulse with the concurrent rise in gonadal vein estradiol levels. Individual symbols represent the results from each of the six men.

T-binding globulin concentrations were similar in peripheral $(11.4 \pm 2.6 \mathrm{ng} \mathrm{T}$ bound $/ \mathrm{ml})$ and gonadal vein serum $(9.3 \pm 3.2 \mathrm{ng}$ $\mathrm{T}$ bound $/ \mathrm{ml}$ ). Therefore, $\sim 97 \%$ of gonadal vein testosterone must be either free or albumin bound.

\section{Discussion}

The results of this study demonstrate that testosterone secretion in adult men occurs in discrete bursts that appear regular in frequency but vary in amplitude, and suggest a cause-effect relationship between pulsatile gonadotropin secretion and normal Leydig cell function in men. The tight coupling of $T$ to $E_{2}$ pulses found in gonadal vein serum indicates that these fluctuations are not artifactual, but instead represent true biological signals. Although mean gonadal vein $T$ levels are 200 times the $E_{2}$ concentrations, the use of a highly specific antiserum after complete chromatographic separation excluded radioimmunoassay crossreactivity as an explanation for these concordant secretory episodes. Mean gonadal vein $\mathrm{T}$ and $\mathrm{E}_{2}$ concentrations in this study are similar to values reported in previous studies in which single blood samples were taken $(16-18)$. The variation in gonadal

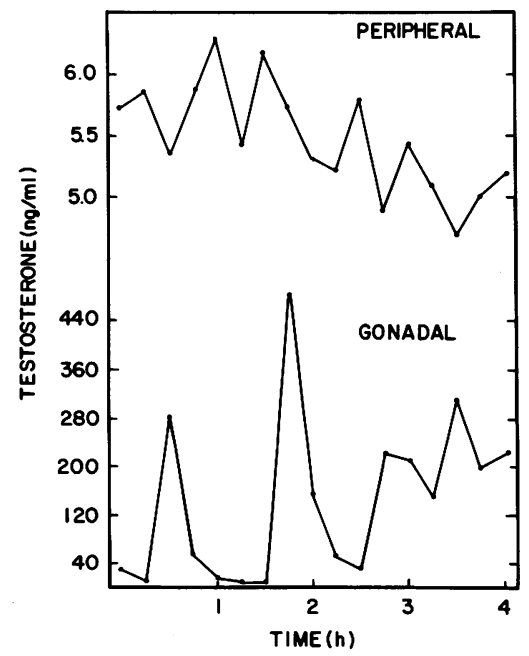

Figure 3. Profiles of $\mathrm{T}$ secretion observed by simultaneous peripheral and gonadal vein blood sampling in a representative subject. Blood was sampled at 15-min intervals for $4 \mathrm{~h}$. 
vein $T$ and $E_{2}$ levels among the men studied may represent, in part, dilution of gonadal vein blood by the circulation of small collateral veins. Additionally, although circulating steroid and gonadotropin levels were within the range of normal in these subjects, testicular function and gonadal vein blood flow are not entirely normal in men with varicocele $(19,20)$.

Why are the $\mathrm{T}$ secretory episodes not clearly evident in the peripheral blood in man, whereas robust $T$ pulses are observed in many experimental animals? To be detected, a hormonal pulse (a) must be of sufficient amplitude to be distinguishable from assay noise, $(b)$ pulse frequency must not be so fast, nor metabolic clearance so prolonged, that the pulse is obscured, and (c) the sampling frequency and duration must be adequate to detect a periodic signal.

There is evidence to suggest that physiologic $\mathrm{T}$ secretion by the human testis is characterized by a state of hyporesponsiveness to gonadotropin stimulation compared with adult males of other species. T fluctuations in the peripheral blood of monkeys (6, $21)$, rams (4, 22), bulls (23), dogs (5), deer (24), rabbits (25), and mice (7) vary in amplitude from 2 to $30 \mathrm{ng} / \mathrm{ml}$, compared with much smaller variations of $<1-3 \mathrm{ng} / \mathrm{ml}$ in men (8-12). We are unaware of any other species in which moment-to-moment changes in testicular vein steroid levels have been studied. Mean $T$ levels rise $\sim 50 \%$ after acute human chorionic gonadotropin (hCG) stimulation in men (26), compared with 3-10-fold rises in experimental animals, including the rhesus monkey $(23,27$, 28). Similarly, when LRH is administered to normal men, although pronounced increments in circulating LH levels occur, there are only slight increases in circulating $T$ levels $(11,29)$. Again, T pulses accompany LH rises after acute LRH administration to lower animals, including monkeys (24, 30-33). The production of testosterone by human and rat Leydig cells after exposure to hCG in vitro has also been compared (34). In that study, hCG produced a 10 -fold greater increase in $\mathrm{T}$ production by rat than by human Leydig cells. Both a smaller LH receptor concentration per Leydig cell and a lesser supply of pregnenolone to microsomal steroidogenic enzymes in the human testis appeared to play a role in this finding. Some caution in the interpretation of those data is needed, however, in that the testes of young adult rats were compared with those of elderly men undergoing orchiectomy as treatment for prostatic cancer. Previous work from our laboratory suggests that aging in men is characterized by a reduction in pregnenolone supply by mitochondria (35). Nevertheless, these results are consistent with the possibility that $\mathrm{T}$ pulses in young adult men are too small in amplitude to be detected in peripheral blood.

The lack of distinct $T$ pulses in peripheral blood in men may also, in part, reflect a frequency-related summation of individual testicular secretory events. Spontaneous $T$ pulses in gonadal vein blood occurred approximately hourly. Although this represents nearly twice most previous estimates of LH pulse frequency in normal men, recent studies in which alpha subunit pulses were used to track gonadotropin secretory episodes (36), or where LH was measured by RIA in peripheral blood samples drawn every 4 min (37), suggest that previous studies may have underestimated spontaneous gonadotropin pulse frequency. In comparison, the more striking circulating $\mathrm{T}$ fluctuations in lower species occur with a frequency that does not appear to exceed one pulse per $2 \mathrm{~h}$. Further, slowing the gonadotropin pulse generator in normal men with fluoxymesterone allowed for the detection of individual $T$ pulses in peripheral blood (38). The metabolic clearance of testosterone, when corrected for body surface area, appears to be similar in humans $\left(560\right.$ liters $/ \mathrm{m}^{2}$ per $24 \mathrm{~h}$; reference 39) and in adult male rhesus monkeys (486 liters $/ \mathrm{m}^{2}$ per $24 \mathrm{~h}$; reference 40 ). Therefore, there is no evidence suggesting a more prolonged half-life of circulating testosterone to explain the lack of detectable $\mathrm{T}$ pulses in men.

Both the duration and frequency of blood sampling are important in establishing the detailed picture of pulsatile hormone secretion. We limited our study to $4 \mathrm{~h}$ because of our concern for possible catheter complications with a longer study. It will be interesting to reexamine testicular steroid secretion with more frequent blood sampling, and to compare the findings with changes in gonadotropin levels. Neither intensive nor prolonged sampling of peripheral blood allows for the identification of convincing $\mathrm{T}$ secretory episodes, nor for their relationship to $\mathrm{LH}$ secretion.

The concordance of $E_{2}$ with $T$ secretory episodes suggests that the Leydig cell, under LH control, is the source of most of the $\mathrm{E}_{2}$ secreted by the adult human testis. This finding is consistent with the observation that aromatase activity is greater in whole testis homogenates than in isolated seminiferous tubules in men (41), that hCG produces a rise in gonadal vein $E_{2}$ levels (16), and with the results of studies in adult male rodents (42). However, additional factors may influence testicular $\mathrm{E}_{2}$ secretion, since there is also a strongly positive correlation coefficient relating circulating $\mathrm{FSH}$ concentrations to intratesticular $\mathrm{E}_{2}$ content among infertile men (43).

\section{Acknowledgments}

Gonadal venography was performed by Drs. Manfred Boehnke and Joseph Lenkey of the Department of Radiology, Montefiore Hospital. We wish to thank Dushan Ghooray for expert technical assistance, Nancy Parham for nursing support, and Patricia Fleming for secretarial assistance.

This work was supported in part by National Institutes of Health grant RO1-19546.

\section{References}

1. Nankin, H. R., and P. Troen. 1976. Repetitive luteinizing hormone elevations in serum of normal men. J. Clin. Endocrinol. Metab. 33:558560.

2. Clarke, I. J., and J. T. Cummins. 1982. The temporal relationship between gonadotropin releasing hormone $(\mathrm{GnRH})$ and luteinizing hormone (LH) secretion in ovariectomized ewes. Endocrinology. 111:17371739.

3. Belchetz, P. E., T. M. Plant, Y. Nakai, E. J. Keogh, and E. Knobil. 1978. Hypophysial responses to continuous and intermittent delivery of hypothalamic gonadotropin-releasing hormone. Science (Wash. DC). 202:631-633.

4. Sanford, L. M., J. S. D. Winter, W. M. Palmer, and B. E. Howland. 1974. The profile of LH and testosterone secretion in the ram. Endocrinology. 95:627-631.

5. DePalatis, L., J. Moore, and R. E. Falvo. 1978. Plasma concentrations of testosterone and LH in the male dog. J. Reprod. Fertil. 52: 201-207.

6. Steiner, R. A., A. P. Peterson, J. Y. L. Yu, H. Conner, M. Gilbert, B. TerPenning, and W. J. Bremner. 1980. Ultradian luteinizing hormone and testosterone rhythms in the adult male monkey, Macaca fascicularis. Endocrinology. 107:1489-1493.

7. Coquelin, A., and C. Desjardins. 1982. Luteinizing hormone and testosterone secretion in young and old male mice. Am. J. Physiol. 243: E257-E263. 
8. Murray, M. A. F., and C. S. Corker. 1973. Levels of testosterone and luteinizing hormone in plasma samples taken at 10-minute intervals in normal men. J. Endocrinol. 56:157-158.

9. Leymarie, P., M. Roger, M. Castanier, and R. Scholler. 1974. Circadian variations of plasma testosterone and estrogens in normal men. A study by frequent sampling. J. Steroid Biochem. 5:167-171.

10. Smith, K. D., R. K. Tcholakian, M. Chowdhury, and E. Steinberger. 1974. Rapid oscillations in plasma levels of testosterone, luteinizing hormone, and follicle-stimulating hormone in men. Fertil. Steril. 25:965-975.

11. Rowe, P. H., P. A. Racey, G. A. Lincoln, M. Ellwood, J. Lehane, and J. C. Shenton. 1975. The temporal relationship between the secretion of luteinizing hormone and testosterone in man. J. Endocrinol. 64:1726.

12. Naftolin, F., H. L. Judd, and S. S. C. Yen. 1973. Pulsatile patterns of gonadotropin and testosterone in man: the effects of clomiphene with and without testosterone. J. Clin. Endocrinol. Metab. 36:285-288.

13. Dufau, M. L., J. D. Veldhuis, F. Fraoli, M. L. Johnson, and I. Z. Beitins. 1983. Mode of secretion of bioactive luteinizing hormone in man. J. Clin. Endocrinol. Metab. 57:993-1000.

14. Nisula, B. C., Y. A. Wilson, and D. L. Loriaux. 1978. Solid phase method for measurement of binding capacity of testosterone-estradiol binding globulin in human serum. Steroids. 31:681-690.

15. Santen, R. J., and C. W. Bardin. 1973. Episodic luteinizing hormone secretion in man. Pulse analysis, clinical interpretation, and physiologic mechanisms. J. Clin. Invest. 52:2617-2628.

16. Weinstein, R. L., R. P. Kelch, M. R. Jenner, S. L. Kaplan, and M. M. Grumbach. 1974. Secretion of unconjugated androgens and estrogens by the normal and abnormal human testis before and after human chorionic gonadotropin. J. Clin. Invest. 53:1-6.

17. Hammond, G. L., A. Roukonen, M. Kontturi, E. Koskela, and R. Vihko. 1977. The simultaneous radioimmunoassay of seven steroids in human spermatic and peripheral venous blood. J. Clin. Endocrinol. Metab. 45:16-24.

18. Leinonen, P. 1980. Estrone and estradiol concentrations in the testis and spermatic and peripheral venous blood of elderly men: the influence of estrogen treatment. J. Steroid Biochem. 13:737-742.

19. Yoshida, K.-I., J. A. LaNasa, Jr., J. Takahashi, S. J. Winters, H. Oshima, and P. Troen. 1982. Studies of the human testis. XVI. Evaluation of multiple indexes of testicular function in relation to advanced age, idiopathic oligospermia, or varicocele. Fertil. Steril. 38:712-720.

20. Green, K. F., T. T. Turner, and S. S. Howards. 1984. Varicocele: reversal of the testicular blood flow and temperature effects by varicocele repair. J. Urol. 131:1208-1211.

21. Plant, T. M. 1981. Time courses of concentrations of circulating gonadotropin, prolactin, testosterone and cortisol in adult male rhesus monkeys (Macaca mulatta) throughout the $24 \mathrm{~h}$ light-dark cycle. Biol. Reprod. 25:244-252.

22. D’Occhio, M. J., B. D. Schanbacher, and J. E. Kinder. 1982. Relationship between serum testosterone concentration and patterns of luteinizing hormone secretion in male sheep. Endocrinology. 110:15471554.

23. Katongole, C. B., F. Naftolin, and R. V. Short. 1971. Relationship between blood levels of luteinizing hormone and testosterone in bulls, and the effects of sexual stimulation. J. Endocrinol. 50:457-466.

24. Lincoln, G. A., and R. N. B. Kay. 1979. Effects of season on the secretion of $\mathrm{LH}$ and testosterone in intact and castrated red deer stags (Cervus elaphaus). J. Reprod. Fertil. 55:75-80.

25. Moor, B. C., and C. V. Younglai. 1975. Variations in peripheral levels of LH and testosterone in adult male rabbits. J. Reprod. Fertil. 42:259-266.

26. Saez, J. M., and M. G. Forest. 1979. Kinetics of human chorionic gonadotropin-induced steroidogenic response of the human testis. I. Plasma testosterone: implications for human chorionic gonadotropin stimulation test. J. Clin. Endocrinol. Metab. 49:278-283.

27. Hodgson, Y. M., G. Urquhart, and D. M. deKretser. 1983. Effect of oestradiol and tamoxifen on the testosterone response in male rats to a single injection of hCG. J. Reprod. Fertil. 68:295-304.

28. Davies, T. F., G. D. Hodgen, M. L. Dufau, and K. J. Catt. 1979. Regulation of primate testicular luteinizing hormone receptors and steroidogenesis. J. Clin. Invest. 64:1070-1073.

29. Judd, H. L., R. Rebar, G. Vandenberg, and S. S. C. Yen. 1974. Effect of luteinizing hormone-releasing factor on Leydig cell function. J. Clin. Endocrinol. Metab. 38:8-13.

30. Lincoln, G. A. 1976. Seasonal variation in the episodic secretion of luteinizing hormone and testosterone in the ram. J. Endocrinol. 69: 213-226.

31. Jones, G. E., K. Baker, D. R. Fahmy, and A. R. Boyns. 1976. Effect of luteinizing hormone releasing hormone on plasma levels of luteinizing hormone, oestradiol, and testosterone in the male dog. $J$. Endocrinol. 68:469-474.

32. Lacroix, A., and J. Pelletier. 1979. LH and testosterone release in developing bulls following LH-RH treatment. Effect of gonadectomy and chronic testosterone propionate pre-treatment. Acta Endocrinol. 91: 719-729.

33. Toivola, P. T. K., W. E. Bridson, and J. A. Robinson. 1978. Effect of luteinizing hormone-releasing hormone on the secretion of luteinizing hormone, follicle-stimulating hormone and testosterone in adult male rhesus monkeys. Endocrinology. 102:1815-1821.

34. Huhtaniemi, I., N. Bolton, P. Leinonen, M. Kontturi, and R. Vihko. 1982. Testicular luteinizing hormone receptor content and in vitro stimulation of cyclic adenosine $3^{\prime} 5^{\prime}$-monophosphate and steroid production: a comparison between man and rat. J. Clin. Endocrinol. Metab. 55:882-889.

35. Takahashi, J., Y. Higashi, J. A. LaNasa, K.-I. Yoshida, S. J. Winters, H. Oshima, and P. Troen. 1983. Studies of the human testis. XVIII. Simultaneous measurement of nine intratesticular steroids: evidence for reduced mitochondrial function in testis of elderly men. $J$. Clin. Endocrinol. Metab. 56:1178-1187.

36. Winters, S. J., and P. Troen. 1985. Pulsatile secretion of immunoreactive $\alpha$-subunit in man. J. Clin. Endocrinol. Metab. 60:344348.

37. Veldhuis, J. D., W. S. Evans, A. D. Rogol, C. R. Drake, M. O. Thorner, G. R. Merriam, and M. L. Johnson. 1984. Intensified rates of venous sampling unmask the presence of spontaneous, high-frequency, pulsations of luteinizing hormone in man. J. Clin. Endocrinol. Metab. 59:96-102.

38. Vigersky, R. A., R. B. Easley, and D. L. Loriaux, 1976. Effect of fluoxymesterone on the pituitary-gonadal axis: the role of testosteroneestradiol-binding globulin. J. Clin. Endocrinol. Metab. 43:1-9.

39. Ito, T., and R. Horton. 1971. The source of plasma dihydrotestosterone in man. J. Clin. Invest. 50:1621-1627.

40. Sholl, S. A., P. T. K. Toivola, and J. A. Robinson. 1979. The dynamics of testosterone and dihydrotestosterone metabolism in the adult male rhesus monkey. Endocrinology. 105:402-405.

41. Payne, A. H., R. P. Kelch, S. S. Musich, and M. E. Halpern. 1976. Intratesticular site of aromatization in the human. J. Clin. Endocrinol. Metab. 42:1081-1087.

42. Tsai-Morris, C. H., D. R. Aquilano, and M. L. Dufau. 1985. Cellular localization of rat testicular aromatase activity during development. Endocrinology. 116:38-46.

43. Takahashi, J., Y. Higashi, J. A. LaNasa, S. J. Winters, H. Oshima, and P. Troen. 1982. Studies of the human testis. XVII. Gonadotropin regulation of intratesticular testosterone and estradiol in infertile men. J. Clin. Endocrinol. Metab. 55:1073-1080. 